\title{
Improvements in 3-D digital mapping for geomorphological and Quaternary geological cartography
}

\author{
C. Ambrosi and C. Scapozza \\ Institute of Earth Sciences (IST), University of Applied Sciences and Arts of Southern Switzerland (SUPSI), \\ Campus Trevano, 6952 Canobbio, Switzerland \\ Correspondence to: C. Scapozza (cristian.scapozza@supsi.ch)
}

Received: 10 July 2014 - Revised: 27 October 2014 - Accepted: 11 November 2014 - Published: 8 April 2015

\begin{abstract}
In recent decades, GIS tools have been directly applied to photo-interpretative geomorphological and geological mapping. Although these tools are powerful and effective tools in the creation of digital maps, it is often very difficult to obtain a correct recognition of the nature and boundaries of geomorphological landforms using two-dimensional images. In addition, the output typically requires some improvements, usually by means of field verifications or using oblique field photographs. The aim of this paper is to present the $\operatorname{ArcGDS}^{\mathrm{TM}}$ tool, which allows the direct exploitation, visualization and digitization of stereoscopic digital linear scanned images (e.g. digital image strips, ${ }^{\odot}$ swisstopo). Through two case studies, we show how 3-D digital mapping makes it possible to produce Quaternary geological and geomorphological maps with a limited complementary fieldwork approach and to provide a quantitative assessment of surface deformations through the acquisition of precise elevation coordinates. Combined with high-resolution digital elevation models, ArcGDS ${ }^{\mathrm{TM}}$ is a powerful tool, particularly over large areas, as well as under forest cover and on very steep slopes.
\end{abstract}

\section{Introduction}

The general application of geographical information systems (GIS) for digitizing, managing, mapping and updating geographical and geological data has become widely accepted over recent decades (e.g. Bonham-Carter, 1994; Carrara and Guzzetti, 1995; Oleschko Lutkova et al., 2008). With the increasing quality and availability of digital topographic maps, undistorted aerial photographs (orthophotos) and highresolution (0.5 up to $5.0 \mathrm{~m}$ ) digital elevation models (DEMs), GIS tools have also been applied to photo-interpretative Quaternary geological and geomorphological mapping (e.g. Gustavsson et al., 2006; Theler et al., 2008; Whitmeyer et al., 2010).

Despite the power of GIS tools for digital mapping, it is often difficult to correctly recognize the nature and the boundaries of geomorphological landforms, unconsolidated sedimentary deposits or landslides on two-dimensional (2-D) images. This applies particularly to steep zones (i.e. rock walls and talus slopes), areas under forest canopies or with very complex topography (as, for example, in rockslide deposit landscapes or in glacier forefields) and in heavily urbanized zones. In many cases, maps represented only by 2-D data must be improved by means of field verifications or, at least, using oblique field photographs (Mihai et al., 2008). On the other hand, our natural perception of the real world is threedimensional (3-D) and is therefore partially impaired by the application of 2-D visualization techniques (Fig. 1) (Schneider and Otto, 2007; Bozzini et al., 2011).

In recent years, high-resolution DEMs have become available in many regions of the world, making it possible to produce detailed hillshades and therefore providing a pseudo3 -D visualization of the relief. A new high-resolution DEM (called swissALTI3-D, ${ }^{\odot}$ swisstopo) has been available in Switzerland since the beginning of 2013 , at all elevations, with an accuracy of $\pm 50 \mathrm{~cm}$ below $2000 \mathrm{~m}$ a.s.l., and \pm 1 $3 \mathrm{~m}$ above $2000 \mathrm{~m}$ a.s.l. (Wiederkehr and Möri, 2013). This constitutes a significant improvement in resolution, particularly at altitudes higher than $2000 \mathrm{~m}$ a.s.l., considering that the previous version of the DEM, called "digitales Höhen- 

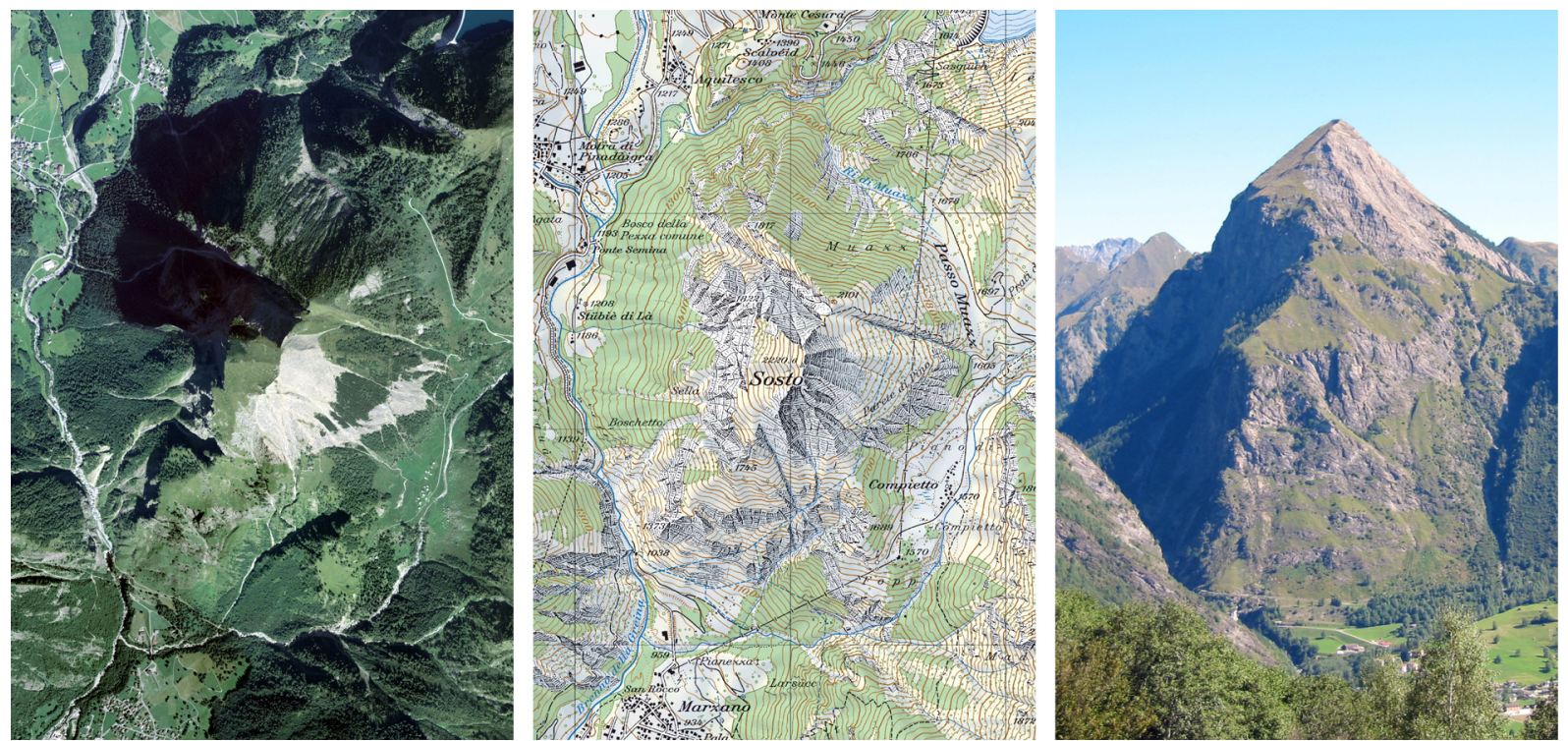

Figure 1. Comparison between the Sosto (2220.6 ma.s.1.) on an aerial orthophotograph $\left({ }^{\circledR}\right.$ swisstopo), the Swiss National Map $1: 25000$ $\left({ }^{\odot}\right.$ swisstopo) and a classical terrestrial oblique photograph $\left({ }^{\circledR} \mathrm{C}\right.$. Scapozza). The mountain symbol of the Blenio Valley (Canton Ticino), with its typical pyramidal form, is directly perceivable only from the terrestrial perspective.

modell" (DHM25), had a surface resolution of $25 \mathrm{~m}$. Nevertheless, there are some limitations related to the production of the swissALTI3-D, especially in zones covered by snow and ice on the aerial photographs used for updating this model, on very steep slopes and in abrupt elevation transitions (Wiederkehr and Möri, 2013).

In order to complement the analysis and interpretation of DEMs, in combination with orthophotographs, which in Switzerland is currently a standard procedure in the production of geological maps (Wiederkehr and Möri, 2013), we present here a new technique which allows the direct exploitation, visualization and digitization of numerical oblique aerial photographs or digital linear scanned image strips, which in Switzerland have a surface resolution of between $18 \times 18 \mathrm{~cm}$ and $50 \times 50 \mathrm{~cm}$. The aim of this contribution is to present a new 3-D digital mapping technique based on the stereoscopic visualization (i.e. based on a pair of stereo images combined to give the perception of 3-D depth) of digital aerial photographs in a GIS environment: ArcGDS ${ }^{\mathrm{TM}}$ (Geosoft Digital System; see http://www.geosoft.it), an extension of the ESRI ${ }^{\circledR}$ ArcGIS $^{\mathrm{TM}}$ software. This extension is particularly adapted for the cartography of high-relief valleys above the timberline and for hillslopes because it can be used to collect, edit and update 3-D features by means of a stereoscopic 3-D interface. Indeed, in addition to 2-D ( $X-Y$ plane coordinates) data, $\operatorname{ArcGDS}^{\mathrm{TM}}$ can also capture high-altitude data ( $Z$ coordinate) by continuously connecting points in superimposed images. This is based on a continuous snap to terrain using image correlation, making it possible to constantly adjust the $Z$ coordinate to the terrain surface when moving in the $X-Y$ plane coordinates.
The distinctive features, potentialities and limits of this technique will be presented through two Cases Studies of photo-interpretative digital mapping based on 3-D visualization using ArcGDS ${ }^{\mathrm{TM}}$ carried out in Switzerland. The first example concerns the Quaternary geological cartography in the framework of GeoCover $\left({ }^{\odot}\right.$ swisstopo), which was executed in Canton Graubünden in the region of Reichenau $\left(46^{\circ} 49^{\prime} \mathrm{N}, 9^{\circ} 25^{\prime} \mathrm{E}\right)$. The second example, on the other hand, concerns the assessment of the rate of displacement along morphostructures affecting both flanks of the Bedretto Valley $\left(46^{\circ} 29^{\prime} \mathrm{N}, 8^{\circ} 28^{\prime} \mathrm{E}\right)$ in Canton Ticino.

\section{3-D digital mapping}

Three-dimensional digital mapping is based on the visualization, through a double polarized screen and polarized glasses, of a pair of digital aerial photographs, which are perfectly superimposed, thereby making it possible to reproduce a stereo representation of the topography depicted in both photographs (Fig. 2). In the case studies presented here, the input data consist of digital strips captured by a linear scanner (12000 pixels), which produce images with a resolution of between 25 and $50 \mathrm{~cm}_{\text {pixel }}{ }^{-1}$. The large, and therefore voluminous, body of data collected allows for a very different and highly professional range of uses, such as 3$\mathrm{D}$ restitution. The strips are all $6 \mathrm{~km}$ wide, but of variable lengths, and are collected by digital airborne pushbroom imagery (i.e. using a line of sensors arranged perpendicularly to the flight direction of the airplane, making it possible to look at a particular area for a longer time, like a long exposure on a camera) executed by the Leica ADS80 airborne digi- 


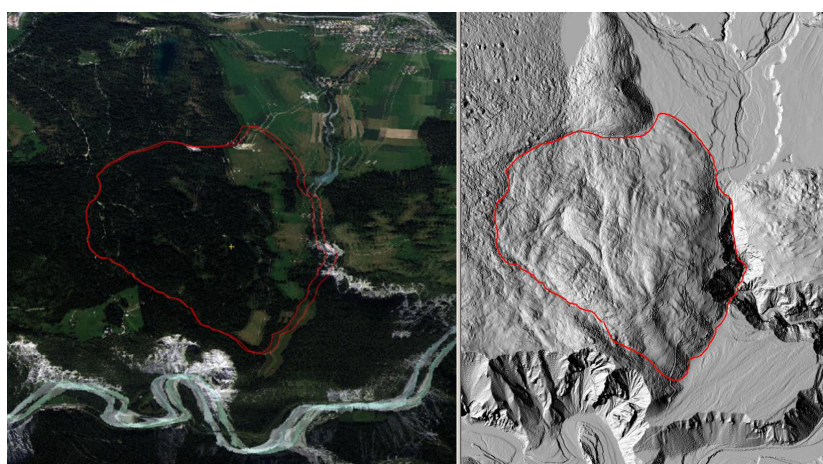

Figure 2. Example of 3-D cartography on the ArcGDS ${ }^{\mathrm{TM}}$ extension. On the left, 3-D cartography window with a stereoscopic visualization of a digital image strip of Sheet $1195 /$ Reichenau $\left({ }^{\circledR}\right.$ swisstopo, 2008); on the right, the final result mapped in 2-D on a $270^{\circ}$ hillshade of the $2 \mathrm{~m}$ pixel resolution DEM ( ${ }^{\circledR}$ swisstopo, 2008).

tal sensor of the Swiss Federal Office of Topography swisstopo (http://www.swisstopo.ch). The digital images are acquired not only in the visible spectra by the red, green and blue channels (RGB), but also by two other sensors covering the consumer infrared (CIR) and providing greyscale tones with a panchromatic sensor (PAN), whose images are sensitive to light of all visible colours. These images are also collected from three different camera angles, therefore also providing a backward scene $\left(16^{\circ}\right)$, a nadir scene $\left(0^{\circ}\right)$ and a forward scene $\left(27^{\circ}\right)$ (Fig. 3). In terms of file format, images are normally provided in a geoTIFF extension (.TIF, .TFW) or in a .SUP, .ADS extension, and are geo-referenced using the WGS84 coordinates system.

In order to exploit the digital aerial photographs for 3-D editing in the ArcGDS ${ }^{\mathrm{TM}}$ software, the images must be converted and oriented so as to avoid compatibility problems with $\operatorname{ArcGDS}^{\mathrm{TM}}$ and with the main GIS software (Fig. 4). This conversion, executed using the ERDAS ER Mapper software, allows the images to be translated from the geoTIFF format to the .ECW format (Enhanced Compression Wavelet). The ArcGDS ${ }^{\mathrm{TM}}$ software itself allows the images to be oriented and converts the data from the .ECW format to the project file with a .GDP extension, allowing it to be edited in an ESRI ${ }^{\circledR}$ ArcGIS $^{\mathrm{TM}}$ environment. This kind of editing means that it is possible to collect perimeters, surface areas and volumes of landforms; create and reshape objects; navigate around the stereoscopic pair of images beginning with a selected point in an ArcMap window; snap to the ground surface using the image correlation when moving in $X-Y$ plane coordinates by continuously adjusting the current $Z$ coordinate to the terrain surface; and modify the elevation ( $Z$ value) of individual vertexes by snapping to the ground surface using the correlation of the pair of images. In particular, the fact of working directly on data supported by the ESRI $^{\circledR}$ ArcGIS $^{\mathrm{TM}}$ system guaranteed data compatibility. Data updating is therefore particularly rapid and easier, and large quantities of data can be managed and amassed. In comparison with classical orthophotographs, 3-D stereoscopic digital strip analysis allows greater accuracy in all coordinates $(X$, $Y, Z$ ) because the unrectified aerial photographs are not affected by the accuracy of the DEMs, which are used to orthorectify the aerial photographs.

\section{Case studies}

\subsection{Case study 1: quaternary geological cartography of Sheet 1195/Reichenau}

In the framework of GeoCover $\left({ }^{(}\right.$swisstopo), in 2012 the Institute of Earth Sciences of the University of Applied Sciences and Arts of Southern Switzerland (SUPSI - Scuola Universitaria Professionale della Svizzera Italiana) developed a 1:25000 digital map of the Quaternary landforms and deposits of Sheet 1195/Reichenau and of parts of sheets 1174/Elm and 1175/Vättis (Fig. 5), located in the northern part of the Canton Graubünden between Flims and Chur (Vorderrhein Valley). This mapping of the Quaternary landforms and deposits was based on the directives of the Swiss Geological Survey (OFEG 2003).

The mapped area is characterized by a complex event stratigraphy, which is well known in the literature (Pollet and Schneider, 2004; Poschinger, 2006a) and which presents a large number of landslides, such as the famous Flims rockslide, deep-seated gravitational slope deformations (DSGSDs) and a range of hillslope and alluvial deposits. This bibliographic knowledge is very important and represents a basis on which to make a correct interpretation of the different deposits and landforms visible through the hillshade of the digital elevation model. In the studied area, different rockslide deposits characterize the valley floor. The first was the Tamins rockslide, which blocked the Vorderrhein River and caused the formation of the Bonaduz palaeo-lake. This first event has not been dated. The Flims rockslide came next and, according to surface exposure dating of boulder and bedrock surfaces related directly to the rockslide, is dated at around $8.9 \pm 0.7 \mathrm{ka}$ (Ivy-Ochs et al., 2009). However, radiocarbon dating of lacustrine sediments overlying the rockslide deposits and of wood fragments contained in the rockslide deposits directly below the lake sediments gives an age of 9.48-9.43 ka cal BP (Deplazes et al., 2007). The Flims rockslide deposits created a new dam of the Vorderrhein River (Poschinger, 2006b), with a reworking and a re-sedimentation of the Bonaduz gravel and the formation of the Ilanz palaeo-lake (Fig. 6; see Wassmer et al., 2004; Poschinger and Kippel, 2009). This lake grew rapidly and initiated a flow caused by the breaking of the dam. Sediments filled up the part of the lake that remained, and, finally, the Vorderrhein River started incising the valley floor from the level of the Flims rockslide deposits (from 840 to more than $1000 \mathrm{~m}$ a.s.l.) down to the current level (from ca. $700 \mathrm{~m}$ a.s.1. 

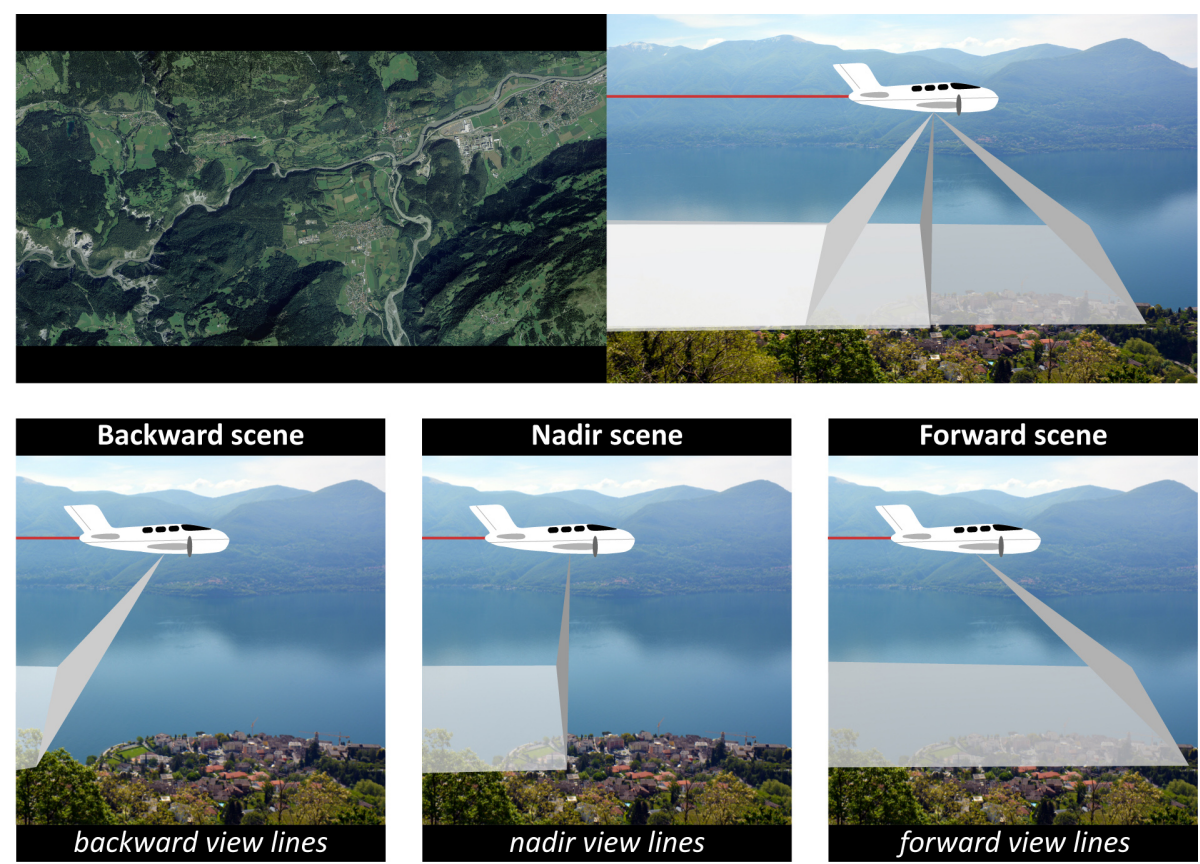

Figure 3. Realization of the digital image of $6 \mathrm{~km}$ wide strips collected by digital airborne pushbroom imagery by the ADS80 airborne digital sensor of the Swiss Federal Office of Topography swisstopo. The acquisition of the three different available scenes (backward, nadir and forward scene) in accordance with the camera angle is also shown. Inspired by a diagram which can be found on http://www.swisstopo.ch/.

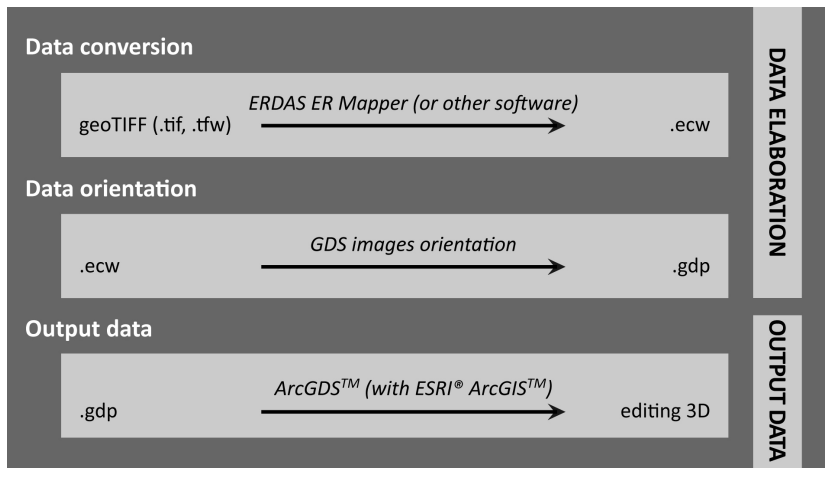

Figure 4. Digital aerial photographs conversion and orientation procedures, making it possible to edit 3-D features in the ArcGDS ${ }^{\mathrm{TM}}$ software.

in Ilanz to ca. $600 \mathrm{~m}$ a.s.l. in Reichenau), creating the Ruinaulta gorges (Poschinger, 2005).

A methodological aspect related to the realization of these digital maps was also to improve the quality of the digitization work by reducing the presence of typical topological errors, which are often generated by applying editing tools to polygons (e.g. cutting, reshaping and clipping tools), where a geological limit is represented by the perimeter of two adjacent polygons. In order to reduce the number of topological errors, and to maintain coherence with the principles of geological mapping, the digitization was performed exclusively by means of polylines (which represent geological construction lines, such as a geological boundary or linear geomorphological landforms) and points. Finally, polygons were generated by a dedicated ESRI ${ }^{\circledR}$ ArcGIS $^{\mathrm{TM}}$ tool called GeoCover_LineMaintoPoly, following the principles of the method "Sion" implemented in the swisstopo digitizing data process (e.g. Sartori et al., 2006; Strasky et al., 2011). In this methodology, the attributes of polygons generated by the intersection of polylines are produced by two kinds of points ("point main" for Quaternary deposits; "point aux" for slope instabilities; Fig. 7). A third kind of point makes it possible to represent punctual geological elements (e.g. erratic boulders, springs).

The analysis and interpretation of 3-D digital image strips with $\operatorname{ArcGDS}^{\mathrm{TM}}$, in combination with orthophotographs and DEMs, makes it possible to perform a detailed digital mapping of Quaternary landforms and deposits, without field verifications. This technique also makes it possible to produce a landform classification with the same accuracy as the legend of the Geological Atlas of Switzerland 1:25000 (OFEG, 2003), which is comprised mainly of field geological mapping. This approach makes it possible to define both kinds of landform and deposit, for large landforms of hillslope instabilities, inside forest canopies and on steep slopes. According to the shape, appearance, morphological characteristics and other identifying elements, it was possible to distinguish six slope and slope foot deposits based on their morphogenetic processes; five glacial and glaciofluvial deposits based on their morphology and age; and five periglacial deposits based 

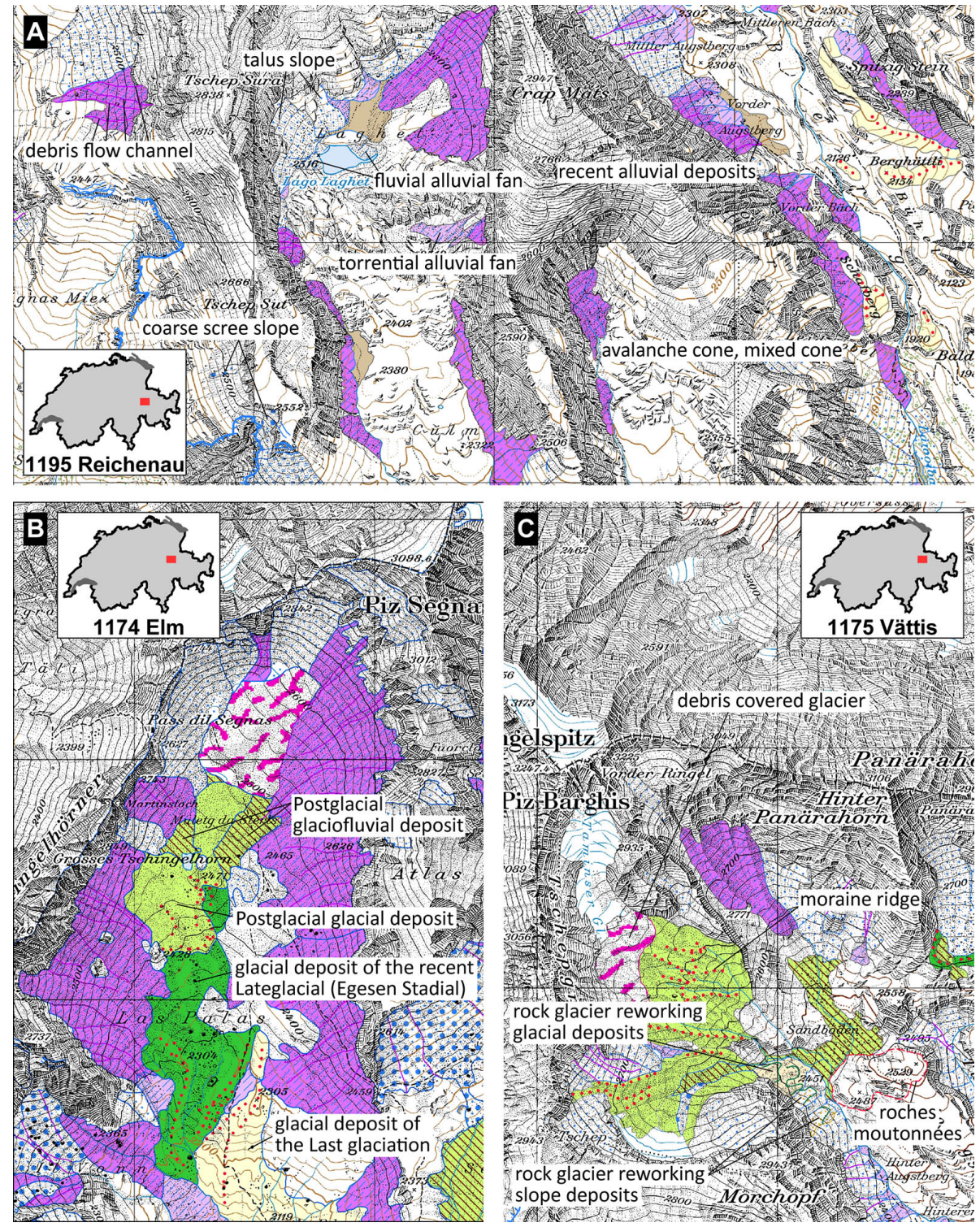

Figure 5. Quaternary geological maps drawn by 3-D digital photo-interpretation for GeoCover $\left({ }^{\odot}\right.$ swisstopo). (a) Extract of Sheet $1195 /$ Reichenau. (b) Extract of Sheet 1174/Elm. (c) Extract of Sheet 1175/Vättis. Basemap: Swiss National Map 1:25000 ( ${ }^{\odot}$ swisstopo, 2012).

on their morphogenetic processes, morphology and age (Table 1).

The classification for slope and slope foot deposits (Fig. 5a), and in particular for cones, was based on the slope angles (e.g. Bertran, 2004). This made it possible to distinguish fluvial alluvial fans (constituted by fluvial deposits) from torrential alluvial fans (mainly constituted by debris flow deposits) and from slope deposits (rockfall to rockslide deposits). The shape (concave or convex), the ground surface granulometry and the presence of morphological indicators such as debris flow gullies, remnants of avalanche cones or permafrost creep lobes (e.g. Francou, 1988; Scapozza, 2013) make it possible to differentiate slope deposits between talus and scree slope deposits, and between avalanche, mixed cones and rockfall deposits s.l. (deposits due to masswasting processes, including coarse-scree slopes).

In terms of glacial deposits (Fig. 5b), it was possible to distinguish their chronostratigraphical situation on the basis of the moraine ridge morphology, the regional situation and an estimation of the depression of the equilibrium line altitude of the glaciers (ELA), corresponding to the zone separating the accumulation zone of a glacier from the ablation zone (see also case study 2) (e.g. Ivy-Ochs et al., 2006). Postglacial deposits are therefore often represented by moraines which are related to the Little Ice Age (AD 1350-1850) or, at least, to the late Holocene (in particular during the Subatlantic, $2.6-0 \mathrm{ka}$ cal BP). They are situated close to the current glaciers, present well-defined moraine ridges consist- 


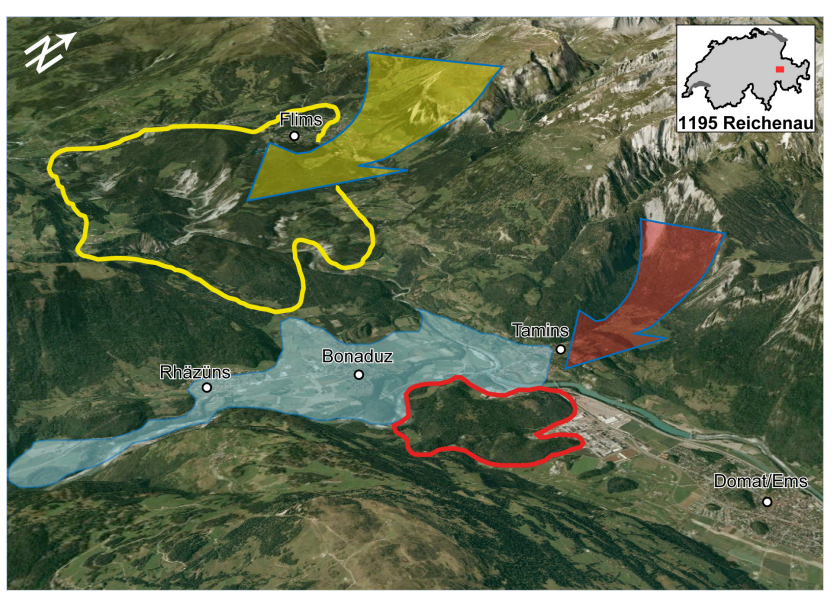

Figure 6. A Google Earth ${ }^{\mathrm{TM}}$ image of the region between Domat/Ems and Flims (Canton Graubünden, Switzerland). In red, the Tamins rockslide; in yellow, the Flims rockslide; and in blue, the zone where the "Bonaduz gravel" was sedimented.

ing of fresh material and are normally un-vegetated. Glacial deposits related to the last glaciation (and deglaciation) include moraines from the Last Glacial Maximum (LGM, ca. 28.0-23.0 ka cal BP), which are not present in the study area, to the end of the Oldest Dryas (ca. 19.0-14.5 ka cal BP). The last glacial stadial before the Bølling-Allerød interstadial (ca. 14.5-12.9 ka cal BP) is known as the Daun Stadial, and it is normally characterized by landform features with well-defined but smoothed moraine ridges with relatively few large boulders, and often overprinted by solifluction processes, which were active during the Younger Dryas (ca. 12.9-11.6 ka cal BP) (Ivy-Ochs et al., 2006). Moraine ridges located just outside the Postglacial deposits and characterized by multi-walled (normally three) sharp crests, often blocky, were considered to belong to the Egesen Stadial, which is normally characterized by three phases of readvancement of valley and cirque glaciers, dating from the Younger Dryas and from the early Holocene (Ivy-Ochs et al., 2007).

Periglacial deposits, in particular rock glaciers (Fig. 5c), were finally differentiated into intact (i.e. active and inactive rock glaciers; sensu Basch, 1996) and relict landforms on the basis of their shape, surface topography, elevation and slope orientation, in accordance with the morphological characteristics listed by Scapozza and Fontana (2009). The morphostratigraphical relationships with glacial and slope deposits also makes it possible to differentiate the origin of the deposits constituting the rock glacier, in line with the classification into talus rock glaciers (alimented by talus deposits) and debris rock glaciers (alimented by glacial deposits) proposed by Barsch (1996).
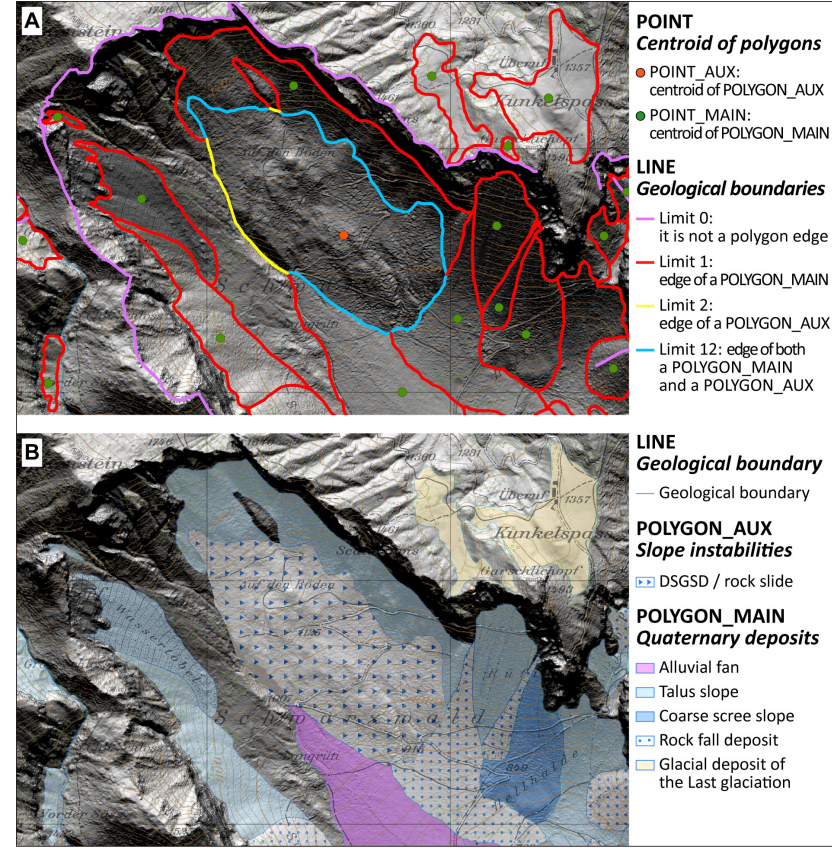

LINE

Geological boundary - Geological boundary POLYGON_AUX Slope instäbilities $\rightarrow$ DSGSD / rock slide POLYGON MAIN Quaternary deposits $\square$ Alluvial fan Talus slope $\checkmark$ Coarse scree slope - Rock fall deposit Glacial deposit of

Figure 7. Extract from the Quaternary geological map of Sheet 1195/Reichenau (GeoCover, ${ }^{\odot}$ swisstopo). (a) Digitization of geological boundaries with polylines and attribution of a deposit with points (centroid of the resulting polygon). (b) Map resulting from the automatic generation of polygons with the ESRI ${ }^{\circledR}$ ArcGIS $^{\mathrm{TM}}$ tool GeoCover_LineMaintoPoly, using the method referred to in the text. Basemaps: Swiss National Map 1:25000 ( ${ }^{\circledR}$ swisstopo, 2012) and $270^{\circ}$ hillshade for the $2 \mathrm{~m}$ pixel resolution DEM ( ${ }^{\circledR}$ swisstopo, 2008).

\subsection{Case study 2: multi-method assessment of slope tectonics activity in Val Bedretto}

The right flank of Val Bedretto is characterized by a series of morphostructures (mainly counterscarps) with displacements of up to $40 \mathrm{~m}$ parallel to the steep-subvertical foliation of the Mesozoic lithologies (Alpine cover units) of the Bedretto zone. Deep-seated gravitational slope deformations (Sackung) and rockslides affect both valley flanks and may play an important role in the development of these morphostructures, which are probably the visible expression of slope tectonics processes (e.g. Jaboyedoff et al., 2011). Three-dimensional digital stereoscopic photogrammetry, together with quantitative geomorphological analysis, will make it possible to assess the genesis of these morphostructures.

In terms of the genesis of these structures, several studies have focused on postglacial uplift and how this interplays with slope deformation (e.g. Ustaszewski and Pfiffner, 2008; Ustaszewski et al., 2008); other authors have focused on a genesis primarily related to active tectonic extension (e.g. Allanic and Gumiaux, 2013). The displacement of several moraine ridges in the area was first observed by Renner (1982), who determined a mean displacement rate 
Table 1. List of slope, slope foot, glacial, glaciofluvial and periglacial deposits differentiated exclusively by 3-D digital photo-interpretation in the framework of Quaternary geological mapping of Sheet 1195/Reichenau and part of the sheets 1174/Elm and 1175/Vättis of GeoCover $\left({ }^{\circledR}\right.$ swisstopo).

\begin{tabular}{|c|c|c|}
\hline Description (English) & Description (Italian) & Description (German) \\
\hline \multicolumn{3}{|l|}{ Slope and slope foot deposits } \\
\hline Fluvial alluvial fan & $\begin{array}{l}\text { Conoide di deiezione preva- } \\
\text { lentemente fluviale }\end{array}$ & Bachschuttkegel \\
\hline Torrential alluvial fan & $\begin{array}{l}\text { Conoide di deiezione preva- } \\
\text { lentemente torrentizio }\end{array}$ & Gemischter Schuttkegel \\
\hline Avalanche cone, mixed cone & $\begin{array}{l}\text { Cono di valanga, cono di } \\
\text { versante di origine mista }\end{array}$ & $\begin{array}{l}\text { Lawinenschuttkegel, } \\
\text { Gemischter Schuttkegel }\end{array}$ \\
\hline $\begin{array}{l}\text { Slope deposit, talus and scree } \\
\text { slope }\end{array}$ & $\begin{array}{l}\text { Deposito di versante, } \\
\text { falde e coni di detrito }\end{array}$ & $\begin{array}{l}\text { Hangschutt, } \\
\text { Hangschuttschleier, } \\
\text { Hangschuttkegel }\end{array}$ \\
\hline Coarse-scree slope & $\begin{array}{l}\text { Deposito di versante a } \\
\text { grossi blocchi }\end{array}$ & Hangschutt mit Blockschutt \\
\hline Rockfall deposit & Deposito di frana di crollo & $\begin{array}{l}\text { Fels- bzw. } \\
\text { Bergsturzablagerung }\end{array}$ \\
\hline \multicolumn{3}{|l|}{ Glacial and glaciofluvial deposits } \\
\hline Postglacial glacial deposit & $\begin{array}{l}\text { Deposito glaciale } \\
\text { postglaciale }\end{array}$ & Postglaziale Moräne \\
\hline $\begin{array}{l}\text { Postglacial glaciofluvial } \\
\text { deposit }\end{array}$ & $\begin{array}{l}\text { Deposito fluvioglaciale } \\
\text { postglaciale }\end{array}$ & $\begin{array}{l}\text { Postglaziale Glazifluviatile } \\
\text { Ablagerungen }\end{array}$ \\
\hline $\begin{array}{l}\text { Glacial deposit of the recent } \\
\text { Lateglacial (Egesen Stadial) }\end{array}$ & $\begin{array}{l}\text { Deposito glaciale del Tar- } \\
\text { doglaciale recente (Stadio } \\
\text { dell'Egesen) }\end{array}$ & $\begin{array}{l}\text { Lokalmoräne } \\
\text { (Egesen-Stadium) }\end{array}$ \\
\hline $\begin{array}{l}\text { Lateglacial glaciofluvial } \\
\text { deposit }\end{array}$ & $\begin{array}{l}\text { Deposito fluvioglaciale tar- } \\
\text { doglaciale }\end{array}$ & $\begin{array}{l}\text { Spätglaziale Glazifluviatile } \\
\text { Ablagerungen }\end{array}$ \\
\hline $\begin{array}{l}\text { Glacial deposit of the last } \\
\text { glaciation }\end{array}$ & $\begin{array}{l}\text { Deposito glaciale } \\
\text { dell'Ultima glaciazione }\end{array}$ & Letzteiszeitliche Moräne \\
\hline \multicolumn{3}{|l|}{ Periglacial deposits } \\
\hline $\begin{array}{l}\text { Rock glacier reworking slope } \\
\text { deposits }\end{array}$ & $\begin{array}{l}\text { Ghiacciaio roccioso che ri- } \\
\text { maneggia i depositi gravita- } \\
\text { tivi }\end{array}$ & $\begin{array}{l}\text { Blockgletscher, der } \\
\text { Hangschutt aufarbeitet }\end{array}$ \\
\hline $\begin{array}{l}\text { Rock glacier reworking glacial } \\
\text { deposits }\end{array}$ & $\begin{array}{l}\text { Ghiacciaio roccioso che ri- } \\
\text { maneggia i depositi glaciali }\end{array}$ & $\begin{array}{l}\text { Blockgletscher, der Morä- } \\
\text { nenmaterial aufarbeitet }\end{array}$ \\
\hline $\begin{array}{l}\text { Relict rock glacier that has } \\
\text { reworked slope deposits }\end{array}$ & $\begin{array}{l}\text { Ghiacciaio roccioso fossile } \\
\text { che ha rimaneggiato i de- } \\
\text { positi gravitativi }\end{array}$ & $\begin{array}{l}\text { Fossiler Blockgletscher, } \\
\text { der Hangschutt } \\
\text { aufgearbeitet hat }\end{array}$ \\
\hline $\begin{array}{l}\text { Relict rock glacier that has } \\
\text { reworked glacial deposits }\end{array}$ & $\begin{array}{l}\text { Ghiacciaio roccioso fossile } \\
\text { che ha rimaneggiato i de- } \\
\text { positi glaciali }\end{array}$ & $\begin{array}{l}\text { Fossiler Blockgletscher, } \\
\text { der Moränenmaterial } \\
\text { aufgearbeitet hat }\end{array}$ \\
\hline Pronival rampart & Nivomorena & Schneehaldemoräne \\
\hline
\end{tabular}




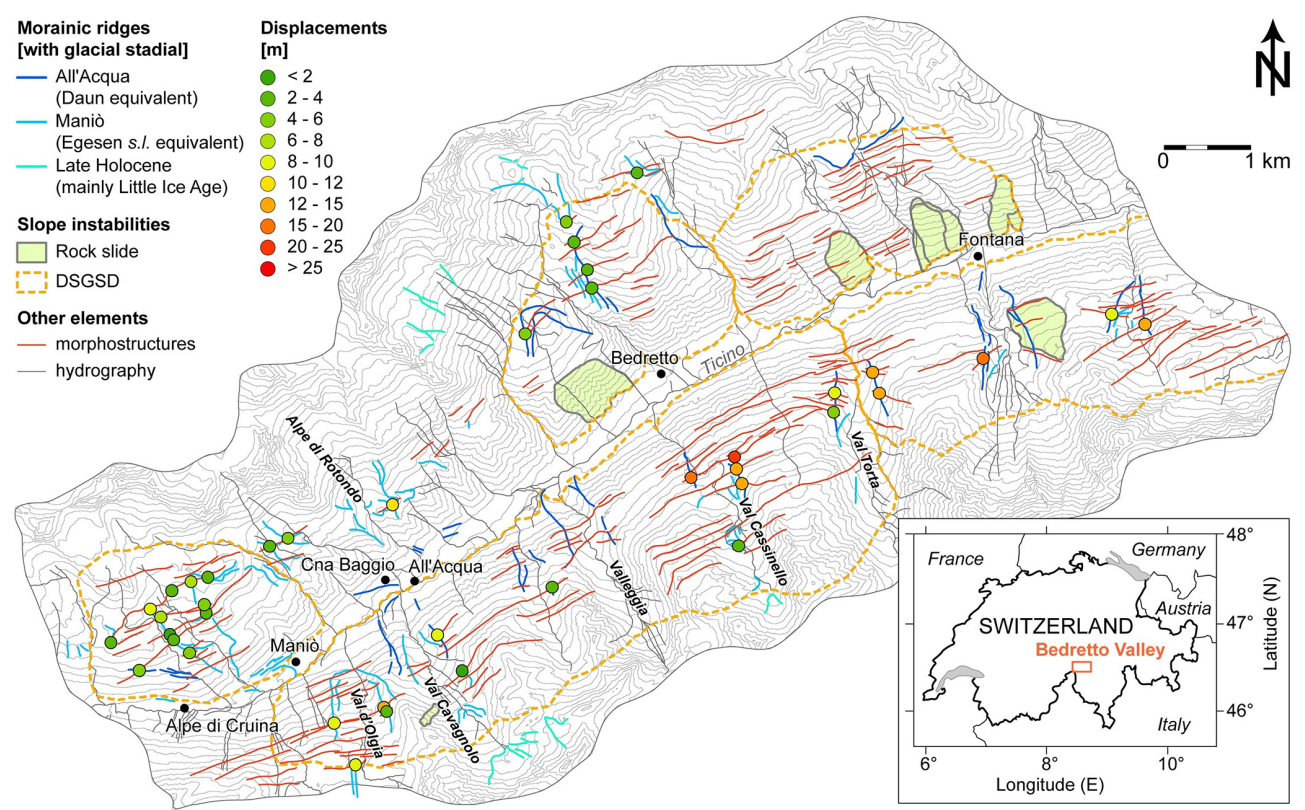

Figure 8. Location of Bedretto Valley and detailed geomorphological map of moraine ridges (see Table 1 for their classification), main rockslides, deep-seated gravitational slope deformations (DSGSDs) and morphostructures, and displacements calculated using 3-D digital photogrammetry. Base map: contour lines calculated on the basis of the swissALTI3-D $2 \mathrm{~m}$ pixel resolution DEM $\left({ }^{\circledR}\right.$ swisstopo, 2012).

based on attributing the moraine ridges to the main stadials of glacier retreat during the Lateglacial. More specifically, Renner (1982) calculated a mean displacement rate of $0.21 \pm 0.18 \mathrm{~mm} \mathrm{a}^{-1}$ for Egesen equivalent stadial moraines (attributed to the Younger Dryas, ca. 12.8-11.7 ka cal BP), and $0.62 \pm 0.10 \mathrm{~mm} \mathrm{a}^{-1}$ for Daun equivalent stadial moraines (attributed to the end of the Oldest Dryas, ca. $14.5 \mathrm{ka} \mathrm{cal} \mathrm{BP}$ ).

Three-dimensional digital photogrammetry (which makes it possible to obtain new instability and geomorphological maps, and to quantify the absolute displacement of the structures), and the age revision and calibration of the glacial (moraines) and periglacial (rock glaciers) landforms of the area, are used to propose a re-evaluation of the role of genetical processes since the end of the Oldest Dryas. In particular, this assessment is based on calculating the displacement rate since the middle of the Lateglacial by merging spatial (absolute displacement of selected morphostructures) and temporal data (age of the deposits merged with the morphostructures). Temporal data were obtained by classifying all the mapped moraine ridges in terms of glacial stadial affiliation. Definition of the glacial stadials in the Bedretto Valley was based on calculating the depression of the equilibrium line altitude of the glaciers (DELA) for all the main local stadials, which were subsequently grouped into regional stadials (Table 2). The ELA was calculated using the accumulation area ratio (AAR) hypsometric method, based on a 0.67 ratio for the accumulation surface/total surface of a glacier (Kerschner, 1976; Gross et al., 1977), corresponding to a ratio of $2: 1$ between the accumulation surface and the ablation sur- face of a glacier. The DELA was calculated on the basis of the altitude difference between the former ELA and the ELA calculated for the end of the Little Ice Age (1850-1860 AD in the central and southern Swiss Alps), considered as the last important glacial stadial with the glaciers in a condition of climatic equilibrium (Dorthe-Monachon and Schoeneich, 1993). Finally, a chronological attribution (i.e. the definition of the minimum age for each glacial stadial; Table 3 ) was performed by means of radiocarbon dating compilation and calibration, the correlation with the North Greenland Ice Core Project (NGRIP) isotopic records and the correlation with the Eastern Alps analogues of the regional glacial stadials, as proposed by Scapozza et al. (2014).

On the basis of the geomorphological mapping performed using a 3-D digital photo-interpretation (Figs. 8 and 9), it is possible to observe that morphostructures are (1) laterally continuous at regional scale parallel to the geological setting, (2) not conditioned by topography and (3) involved in deep slope instabilities such as rockslides and DSGSDs. Digital photogrammetry was used to measure the absolute displacement of 41 morphostructures, with values lying between 0.9 and $32.6 \mathrm{~m}$, and with an accuracy of $\pm 10 \mathrm{~cm}$ (Fig. 8). Taking into account the age of the deposits merged with the morphostructures, displacement rates ranging from 0.1 to $2.2 \mathrm{~mm} \mathrm{a}^{-1}$ were calculated. They show a non-homogeneous spatial and temporal distribution, suggesting that various factors affect the development of the observed morphostructures. Based on the age calibration of moraine ridges, the mean displacement rate values referring to different peri- 
Table 2. Definition of the reference values of the DELA for the Ticino glacier in Bedretto Valley during the Lateglacial. The reference values (with the reference positions C, M, etc. defined by Renner, 1982) are based on the glacial positions occurring on the valley bottom (section "Val Bedretto"). The DELA values for the lateral cirques of the entire Bedretto Valley are also shown.

\begin{tabular}{|c|c|c|c|c|c|c|}
\hline Local stadial & \multicolumn{2}{|c|}{$\begin{array}{l}\text { Corresponding } \\
\text { regional stadial }\end{array}$} & $\begin{array}{l}\text { ELA } 2: 1 \\
\text { (m a.s.1.) }\end{array}$ & $\begin{array}{l}\text { Ref. } 1850 \\
\text { (ma.s.1.) }\end{array}$ & $\begin{array}{l}\text { DELA } \\
(\mathrm{m} / 1850)\end{array}$ & $\begin{array}{l}\text { Corresponding stadial } \\
\text { of the Eastern Alps }\end{array}$ \\
\hline \multicolumn{7}{|l|}{ Val Bedretto } \\
\hline Airolo & - & Airolo & 2075 & 2735 & 660 & Gschnitz \\
\hline Fontana & - & Fontana & 2165 & 2600 & 435 & Clavadel/Senders \\
\hline All'Acqua & A1 & All' Acqua & 2300 & 2600 & 300 & \\
\hline Cassina Baggio & $\mathrm{A} 2$ & Cassina Baggio & 2325 & 2600 & 275 & Daun \\
\hline Maniò & M1 & Maniò & 2375 & 2610 & 235 & Egesen I \\
\hline Alpe di Cruina & $\mathrm{M}$ & Alpe di Cruina & 2420 & 2535 & 115 & Egesen II (Bocktentälli) \\
\hline Val Corno & $\mathrm{C}$ & Corno & 2470 & 2535 & 65 & Egesen III (Kartell) \\
\hline Gh. del Corno & LIA & Little Ice Age & 2535 & 2535 & 0 & Little Ice Age \\
\hline \multicolumn{7}{|l|}{ Val Torta } \\
\hline Piano di Pescia & $\mathrm{A} 2$ & Cassina Baggio & 2270 & 2550 & 280 & Daun \\
\hline Stabiello Grande & M1 & Maniò & 2330 & 2550 & 220 & Egesen I \\
\hline Torta 1 & M & Alpe di Cruina & 2410 & 2550 & 140 & Egesen II \\
\hline Torta 2 & $\mathrm{C}$ & Corno & 2480 & 2550 & 70 & Egesen III \\
\hline Torta 3 & LIA & Little Ice Age & 2550 & 2550 & 0 & Little Ice Age \\
\hline \multicolumn{7}{|l|}{ Val Cassinello } \\
\hline Folcra di Mezzo & $\mathrm{A} 2$ & Cassina Baggio & 2120 & 2400 & 280 & Daun \\
\hline Folcra & M1 & Maniò & 2150 & 2400 & 250 & Egesen I \\
\hline Cassinello & $\mathrm{M}$ & Alpe di Cruina & 2220 & 2400 & 180 & Egesen II \\
\hline Val Cassinello & $\mathrm{C}$ & Corno & 2330 & 2400 & 70 & Egesen III \\
\hline Gh. di Cassinello & LIA & Little Ice Age & 2400 & 2400 & 0 & Little Ice Age \\
\hline \multicolumn{7}{|l|}{ Valleggia } \\
\hline Selva & A1 & All'Acqua & 2260 & 2575 & 315 & Daun \\
\hline Gh. di Valleggia & LIA & Little Ice Age & 2575 & 2575 & 0 & Little Ice Age \\
\hline \multicolumn{7}{|l|}{ Val Cavagnolo } \\
\hline Cassina Baggio & A3 & Cassina Baggio & 2225 & 2505 & 280 & Daun \\
\hline Formazzora & M1 & Maniò & 2270 & 2505 & 235 & Egesen I \\
\hline Cassinello & M & Alpe di Cruina & 2380 & 2505 & 125 & Egesen II \\
\hline Gh. di Cavagnolo & LIA & Little Ice Age & 2505 & 2505 & 0 & Little Ice Age \\
\hline \multicolumn{7}{|l|}{ Val d'Olgia } \\
\hline Al Lago & M1 & Maniò & 2295 & 2495 & 200 & Egesen I \\
\hline All'Uomo & $\mathrm{M}$ & Alpe di Cruina & 2360 & 2495 & 135 & Egesen II \\
\hline Ganone & $\mathrm{C}$ & Corno & 2400 & 2495 & 95 & Egesen III \\
\hline Gh. d'Olgia & LIA & Little Ice Age & 2495 & 2495 & 0 & Little Ice Age \\
\hline \multicolumn{7}{|l|}{ Pizzo Gallina } \\
\hline Nufenen & M & Alpe di Cruina & 2580 & 2705 & 125 & Egesen II \\
\hline Chilchhorn & $\mathrm{C}$ & Corno & 2620 & 2705 & 85 & Egesen III \\
\hline Gh. di Gallina & LIA & Little Ice Age & 2705 & 2705 & 0 & Little Ice Age \\
\hline \multicolumn{7}{|l|}{ Alpe di Rotondo } \\
\hline Grasso dei Larici & A4 & Cassina Baggio & 2335 & 2630 & 295 & Daun \\
\hline Bosco & M1 & Maniò & 2395 & 2630 & 235 & Egesen I \\
\hline A. di Rotondo & M & Alpe di Cruina & 2500 & 2630 & 130 & Egesen II \\
\hline Chüebodengl. & LIA & Little Ice Age & 2630 & 2630 & 0 & Little Ice Age \\
\hline
\end{tabular}


Table 3. Correlation of the reference regional stadials for the Ticino glacier in Bedretto Valley with the Eastern Alps model, and proposal for the calibrated minimum age based on the radiocarbon dating compilation and calibration performed by Scapozza et al. (2014).

\begin{tabular}{lrr|lr|c}
\hline \multicolumn{2}{c}{ Bedretto Valley (Scapozza et al., 2014) } & \multicolumn{2}{c|}{ Eastern Alps (Maisch, 1982) } & \multicolumn{1}{c}{ Chronology } \\
\hline \multicolumn{2}{l}{ Regional glacial stadial } & DELA (m/1850) & Glacial stadial & DELA (m/1850) & Minimal age (ka cal BP) \\
\hline Airolo & - & 660 & Gschnitz & $600-700$ & 17.0 \\
Fontana & - & 435 & Clavadel/Senders & $380-420$ & 15.5 \\
All’Acqua & A1 & $300-315$ & Daun & $250-350$ & 15.0 \\
Cassina Baggio & A2 & $280-295$ & & & 14.5 \\
Maniò & M1 & $200-250$ & Egesen I & $170-240$ & 12.5 \\
Alpe di Cruina & M & $115-180$ & Egesen II (Bocktentälli) & $100-150$ & 11.7 \\
Val Corno & C & $65-95$ & Egesen III (Kartell) & $60-120$ & 11.2 \\
\hline
\end{tabular}

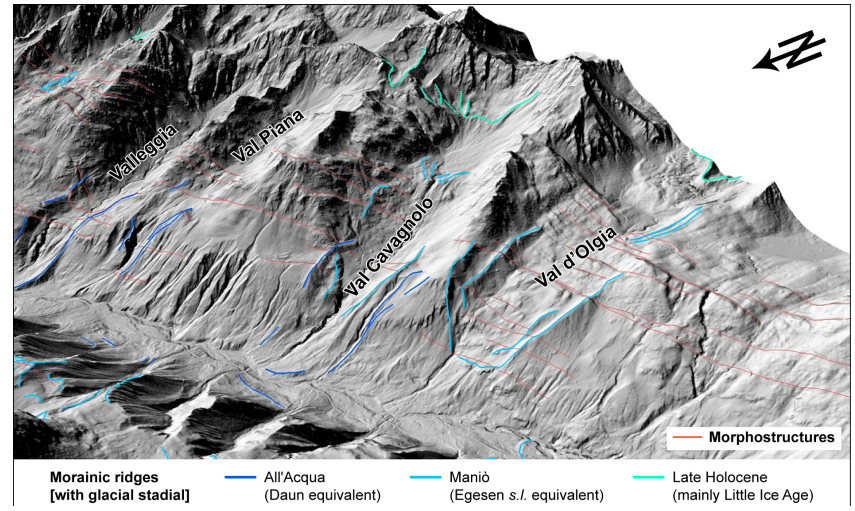

Figure 9. Three-dimensional visualization of the right side of the Bedretto Valley, focusing on the moraines and morphostructures of Val d'Olgia and Val Cavagnolo (location in Fig. 8). Basemap: hillshade calculated on the swissALTI3-D $2 \mathrm{~m}$ pixel resolution DEM $\left({ }^{\circledR}\right.$ swisstopo, 2012).

ods were calculated (Fig. 10a) and used to classify the entire data set (Fig. 10b). The mean displacement rate for the whole Holocene, determined on the basis of the values referring only to the moraine ridges of the Alpe di Cruina stadial (Egesen II), is generally lower than $0.5 \mathrm{~mm} \mathrm{a}^{-1}$ and does not correlate with the age, as indicated by the very low determination coefficient $\left(R^{2}=0.02\right)$, as obtained using linear regression. This regular displacement of $0.4 \pm 0.08 \mathrm{~mm} \mathrm{a}^{-1}$ for the last $11.7 \mathrm{ky}$ may be assumed to be representative of (neo)tectonic activity. This represents a regular base deformation over several millennia independent in terms of the ages of the structures, indicating that these displacements are controlled mainly by endogenic processes.

Lateglacial data showing a displacement significantly higher than the Holocene mean value present an exponential increase with age (with a determination coefficient of $R^{2}$ of 0.52 ; Fig. 10b). This behaviour is consistent with numerical models of postglacial slopes debuttressing, and it implies a condition of continuous dynamic equilibrium with slow displacement rates after an initial paroxystic phase following deglaciation (e.g. Ustaszewski et al., 2008; Ambrosi and
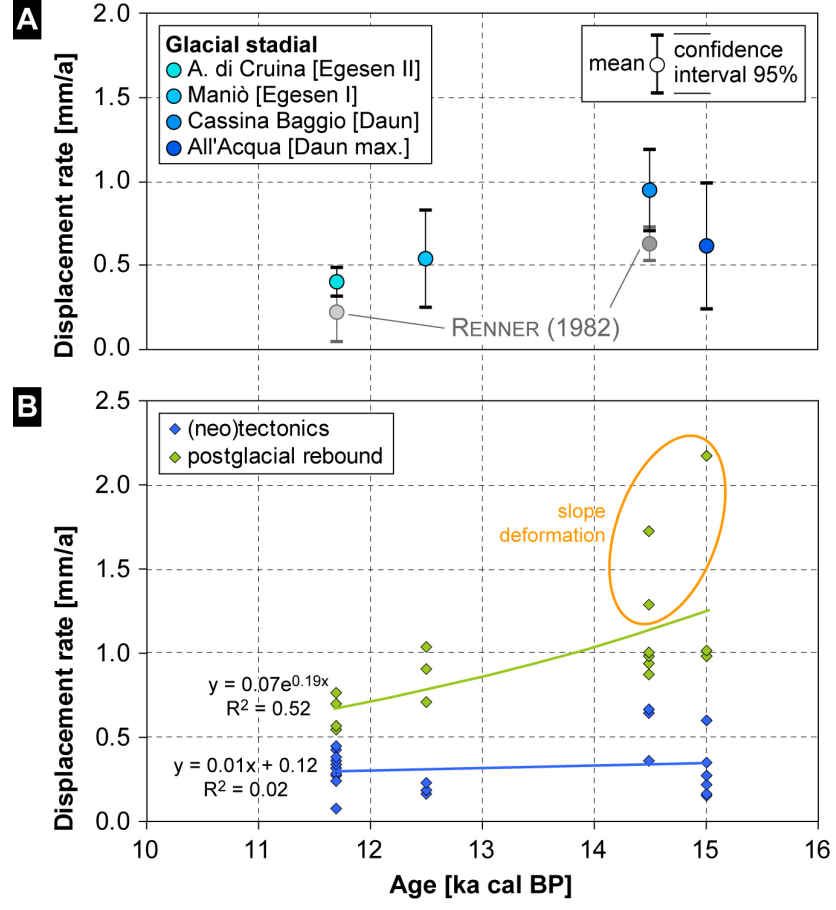

Figure 10. Slope structures displacement rates in Bedretto Valley, calculated using 3-D digital photogrammetry. (a) Mean values and $95 \%$ confidence interval of the displacements classed on the basis of the calibrated age of the incised moraine ridges. The displacement rates calculated on the basis of the values of moraine ridges displacement reported by Renner (1982) are also presented: 1-4 m for Maniò s.l. stadial moraines (Egesen equivalent) and 8-10 $\mathrm{m}$ for All' Acqua s.l. stadial moraines (Daun equivalent). (b) Displacement rates calculated on the basis of morphostructure displacements and of the age of the incised moraine ridges, and classified according to their origin. For (neo)tectonics, values reflect the mean displacement calculated in (a) for the whole of the Holocene epoch.

Crosta, 2011). It is therefore possible to refer deformations comprising between 0.5 and $1.0 \mathrm{~mm} \mathrm{a}^{-1}$ to the postglacial uplift during the Lateglacial period, particularly between 17.0 and $14.5 \mathrm{ka} \mathrm{cal} \mathrm{BP}$. Higher values (i.e. $>1 \mathrm{~mm} \mathrm{a}^{-1}$ ) were 
always measured within the perimeter of deep slope deformations, which probably have the effect of locally emphasizing the movements related to (neo)tectonics and postglacial uplift, and of explaining displacement rates higher than $1 \mathrm{~mm} \mathrm{a}^{-1}$. For now, the measurements taken using 3D digital photogrammetry do not make it possible to confirm whether, after a triggering and acceleration phase, the deep slope deformations may have moved at a relatively constant rate during the end of the Lateglacial and over the entire Holocene epoch, as suggested by Ambrosi and Crosta (2006). These displacement values higher than $1 \mathrm{~mm} \mathrm{a}^{-1}$ are normally associated, within Alpine regions characterized by very active tectonics, with active faults (e.g. Galadini et al., 2001; Allanic and Gumiaux, 2013). Since the Bedretto Valley is seismically inactive at present, for displacement rates higher than Holocene mean values $\left(>0.5 \mathrm{~mm} \mathrm{a}^{-1}\right)$, active tectonics seems to have played a minor role in the origin of the observed morphostructures.

In conclusion, therefore, the displacement rate values calculated using 3-D digital photogrammetry make it possible to formulate some preliminary propositions regarding the origin of the morphostructures observed in the Bedretto Valley and the evolution of their movements. Most of the observed morphostructures originated from postglacial uplift during the late Pleistocene and from the (neo)tectonic movement during the Holocene along pre-existing geologically steep planes. However, higher displacement rates suggest a significant slope deformation factor with regard to the formation of the observed morphostructures.

\section{Discussion and conclusion}

As presented and discussed in the above two case studies, 3-D digital mapping using ArcGDS $^{\mathrm{TM}}$ represents a powerful method, not only for producing Quaternary geological or geomorphological maps but also for making a quantitative assessment of surface deformations through the acquisition of precise elevation coordinates on stereoscopic digital image strips.

In terms of digital geological mapping, in addition to the standard procedure combining the analysis and interpretation of orthophotographs and DEMs (Wiederkehr and Möri, 2013), 3-D digital mapping makes it possible to observe both the real shape of the landforms and the extent to which this shape was effectively evident (Table 4). This is particularly appropriate below the timberline (subalpine regions), where forest is present. Landforms lying under forest cover are often masked by vegetation on orthophotographs. On DEMs, elevation data do not show the same accuracy as those recorded in un-vegetated areas because of the difficulty encountered in correctly defining the ground surface elevation. Three-dimensional stereoscopic vision is also suitable for steep slopes, where orthophotographs present shadows depending on the slope orientation and where it is not possible to avoid uneven and abrupt transitions in the event of major elevation differences on DEMs, particularly those above $2000 \mathrm{~m}$ a.s.l. for the swissALTI3-D (Wiederkehr and Möri, 2013). Since data for the third dimension (elevation) is also collected (with $\operatorname{ArcGDS}^{\mathrm{TM}}$ ), it is possible to understand the geometric relationships between different landforms, and also potentially reconstruct a historical sequence of the main events. A relative-dated event stratigraphy can therefore be defined, based on the morphostratigraphy principles (continuity, superposition and cross cutting of the landforms). This approach was adopted for dating the glacial, glaciofluvial and periglacial deposits mapped in the Quaternary geological cartography framework performed in the GeoCover $\left({ }^{\circ}\right.$ swisstopo) (case study 1$)$. Taking in account these three characteristics (suitability under forest cover, on steep slopes and in the definition of geometric relationships between landforms), 3-D digital mapping on image strips is particularly appropriate, for example, for the compilation of landslide inventory maps on a regional scale. Documents of this type are particularly significant when making landslide hazard assessments with regard to making prudent decisions in terms of sustainable territorial planning. This was the case for the Bedretto Valley example presented here (case study 2), where landslides perimeters were mapped and their activity assessed. The 3-D photo-interpretation methodology can provide information on the landslide type, three-dimensional extension (i.e. volume), relative activity, geometry, involved rock or soil material mass. Landslides can be easily recognized by means of this approach, and geomorphological features associated with mass movements - such as scarps, counterscarps, trenches, debris flows, rockfalls and debris fans - can also be mapped. Based on these morphological characteristics, it will be also possible to define a qualitative state of activity (not based directly on their velocity), leading to the definition of landslide intensity (low, medium and high), in accordance with the landslide hazard degree calculation guidelines developed in Switzerland (Lateltin et al., 2005).

Concerning the quantitative assessment of slope deformations performed to evaluate the slope tectonic activity in the Bedretto Valley (case study 2), the level of precision achieved by 3-D digital photogrammetry on the elevation definition on image strips (accuracy of $\pm 10 \mathrm{~cm}$ ), by snapping the ground surface by image correlation, was higher than that of the high-resolution DEM. This is particularly evident above $2000 \mathrm{~m}$ a.s.1., where the accuracy of the swissALTI3$\mathrm{D}$ is usually between \pm 1 and $3 \mathrm{~m} 1 \sigma$ (66.7\% probability) (Wiederkehr and Möri, 2013).

Photo-interpretation of digital strips is based on the visual analysis of RGB images. This made it possible to resolve interpretation ambiguities of hillshaded DEMs, which depend on illumination altitude and azimuth, and on the kind of land cover (soil, unconsolidated deposits or bedrock). These characteristics are, indeed, fundamental for the correct interpretation of accumulation landforms such as moraines, talus 
Table 4. Comparison between the potentialities of hillshaded DEMs and orthophotographs (2-D mapping) and 3-D digital aerial image strips for the Quaternary geological and geomorphological mapping. The 3-D digital image strips are a unique method making it possible to observe the real shape of the landforms and the extent to which this shape is effectively evident.

\begin{tabular}{lll}
\hline Hillshade of the DEM & $\begin{array}{l}\text { Aerial photograph or } \\
\text { orthophotograph }\end{array}$ & 3-D digital image strip \\
\hline Kind of landform & Kind of deposit & Kind of landform and deposit \\
\hline Below 2000 m a.s.l. & Outside the forest cover & $\begin{array}{l}\text { Also inside the forest cover (for large land- } \\
\text { forms as hillslope instabilities) }\end{array}$ \\
\hline $\begin{array}{l}\text { (Above 2000 m a.s.l. with } \\
\text { the new SwissALTI3-D) }\end{array}$ & $\begin{array}{l}\text { Above the timberline, } \\
\text { difficulties in steep slopes }\end{array}$ & Above the timberline and also in steep slopes \\
\hline
\end{tabular}

slopes or rockfall deposits. Despite the many positive aspects related to the application of the $\operatorname{ArcGDS}^{\mathrm{TM}}$ tool for 3-D digital mapping, it is also important to mention some limitations associated with this method. Firstly, 3-D digital mapping is time-consuming because it is necessary to focus the two images (stereo-correlation) in order to obtain a correct definition of the elevation for every collected data point. Combined with the use of polarized glasses, this makes 3-D mapping very tiring on the eyes, and therefore limits the number of daily working hours of one person. This problem can be overcome by combining the use of the 3-D stereoscopic digital images with hillshaded DEMs, leading to the verification or acquisition of three-dimensional features only when strictly necessary. Examples of such cases would be when interpreting deposit types, when mapping features below the forest cover, when delimiting perimeters and calculating the volume of hillslope instabilities or when defining the highprecision elevation data needed to calculate the displacement or movement of material.

In this communication, we highlight the use and potential of 3-D digital mapping for drawing detailed Quaternary geological and geomorphological maps with limited complementary fieldwork. Combined with the high-resolution swissALTI3-D DEM, ArcGDS ${ }^{\mathrm{TM}}$ represents a powerful tool for digital mapping, particularly when the mapped regions are very extensive or difficult to access for logistical reasons (absence of roads, footpaths, bridges, etc.), or due to particular topographic characteristics, such as the presence of steep slopes, gorges, dense forest cover, etc. Photo-interpretative maps, compiled in accordance with the methodology proposed here, constitute the base document making it possible to define the sediment storage units and the main depositional process involved in their creation. This is fundamental in order to explain, by application of morphostratigrapic principles, the relationships between the different sediment storage units (concept of the sediment cascades) and the relative ages of the mapped landforms.

Acknowledgements. We would like to thank Claudio Castelletti and Linda Soma of the Institute of Earth Sciences SUPSI, and
Pauline Baland and Andreas Möri of the Swiss Geological Survey, Federal Office of Topography swisstopo. Special thanks go to the handling editor, Philip (Phil) Greenwood, as well as Jan Hardie for proofreading the English.

Edited by: P. Greenwood

Reviewed by: two anonymous referees

\section{References}

Allanic, C. and Gumiaux, C.: Are there active faults within the Lepontine dome (Central Alps)?, B. Soc. Geol. Fr., 184, 427-440, doi:10.2113/gssgfbull.184.4-5.427, 2013.

Ambrosi, C. and Crosta, G. B.: Large sackung along major tectonic features in the Central Italian Alps, Eng. Geol., 83, 183-200, doi:10.1016/j.enggeo.2005.06.031, 2006.

Ambrosi, C. and Crosta, G. B.: Valley shape influence on deformation mechanisms of rock slopes, in: Slope tectonics, Geological Society, London, England, Special Publications, 351, 215-233, 2011.

Barsch, D.: Rockglaciers. Indicators for the present and the former geoecology in high mountain environments, Springer, Berlin Heidelberg, Germany, 331 pp., 1996.

Bertran, P. (Ed.): Dépôts de pente continentaux. Dynamique et faciès, Quaternaire, Hors-Série 1, 258 pp., 2004.

Bonham-Carter, G.: Geographic Information Systems for geoscientists: modelling with GIS, Elsevier, Oxford, England, 416 pp., 1994.

Bozzini, C., Conedera, M., and Krebs, P.: La monofotogrammetria. L'evoluzione di uno strumento per il monitoraggio, la pianificazione e la storia del paesaggio, Archi, 2, 45-51, 2011.

Carrara, A. and Guzzetti, F.: Geographical information systems in assessing natural hazards, Kluwer Academic Publishers, Norwell (MA), USA, 355 pp., 2005.

Deplazes, G., Anselmetti, F. S., and Hajdas, I.: Lake sediments deposited on the Flims rockslide mass: the key to date the largest mass movement of the Alps, Terra Nova, 19, 252-258, doi:10.1111/j.1365-3121.2007.00743.x, 2007.

Dorthe-Monachon, C. and Schoeneich, P.: Ligne d'équilibre des glaciers : le stade de référence de 1850 dans les Alpes calcaires occidentales, Geogr. Helv., 48, 125-134, doi:10.5194/gh48-125-1993, 1993. 
Francou, B.: L'éboulisation en haute montagne, $\mathrm{PhD}$ thesis, C.N.R.S., Université de Paris VII, France, 662 pp., 1988.

Galadini, F., Meletti, C., and Vittori, E.: Major active faults in Italy: available surficial data, Neth. J. Geosci., 80, 273-296, 2001.

Gross, G., Kerschner, H., and Patzelt, G.: Methodische Untersuchungen über die Schneegrenze in alpinen Gletschergebieten, Zeitschrift für Gletscherkunde und Glazialgeologie, 12, 223251, 1977.

Gustavsson, N., Kolstrup, E., and Seijmonsbergen, A. C.: A new symbol-and-GIS based detailed geomorphological mapping system: renewal of scientific discipline for understanding landscape development, Geomorphology, 77, 90-111, doi:10.1016/j.geomorph.2006.01.026, 2006.

Ivy-Ochs, S., Kerschner, H., Kubik, P. W., and Schlüchter, C.: Glacier response in the European Alps to Heinrich Event 1 cooling: the Gschnitz stadial, J. Quaternary Sci., 21, 115-130, doi:10.1002/jqs.955, 2006.

Ivy-Ochs, S., Kerschner, H., and Schlüchter, C.: Cosmogenic nuclides and the dating of Lateglacial and Early Holocene glacier variations: The Alpine perspective, Quatern. Int., 164-165, 5363, doi:10.1016/j.quaint.2006.12.008, 2007.

Ivy-Ochs, S., Poschinger, A. v, Synal, H.-A., and Maisch, M.: Surface exposure dating of the Flims landslide, Graubünden, Switzerland, Geomorphology, 103, 104-112, doi:10.1016/j.geomorph.2007.10.024, 2009.

Jaboyedoff, M., Crosta, G. B., and Stead, D.: Slope tectonics: a short introduction, in: Slope tectonics, Geological Society, London, England, Special Publications, 351, 1-10, 2011.

Kerschner, H.: Untersuchungen zum Daun- und Egesenstadium in Nordtirol und Graubünden (methodische Überlegungen), Geographischer Jahresbericht aus Osterreich, 36, 26-49, 1976.

Lateltin, O., Haemmig, C., Raetzo, H., and Bonnard, C.: Landslide risk management in Switzerland, Landslides, 2, 313-320, doi:10.1007/s10346-005-0018-8, 2005.

Maisch, M.: Zur Gletscher- und Klimageschichte des alpinen Spätglazials, Geogr. Helv., 37, 93-104, doi:10.5194/gh-37-93-1982, 1982.

Mihai, B., Şandric, I., and Chiţu, Z.: Some contributions to the drawing of the general geomorphic map using GIS tools. An application to Timis Mountains (Curvature Carphatians), Revista de geomorfologie, 10, 39-50, 2008.

OFEG: Instructions pour la représentation des formes quaternaires et autres signes et symboles lors de la mise au net des cartes originales de l'Atlas géologique de la Suisse 1:25'000, Office fédéral des eaux et de la géologie (OFEG; aujourd'hui Office fédéral de l'environnement, OFEV), Berne, Suisse, 2003.

Oleschko Lutkova, K., Cherkasov, S., Palacio Preto, J. L., Torres Argüelles, V., Gaona Salado, C. I., Castañeda Miranda, A. G., and Zamora Castro, S. A.: GIS in geology and earth sciences, 4th International Conference In Vista of New Approaches for the Geoinformatics, Queretaro, Mexico, 22-26 October 2007, AIP Conference Proceedings, 1009, 1-288, 2008.

Pollet, N. and Schneider, J.-L. M.: Dynamic disintegration processes accompanying transport of the Holocene Flims sturzstrom (Swiss Alps), Earth Planet. Sc. Lett., 221, 433-448, doi:10.1016/S0012-821X(04)00071-8, 2004.

Poschinger, A. v.: Der Flimser Bergsturz als Staudamm, Swiss Bulletin for Applied Geology, 10, 33-47, 2005.
Poschinger, A. v.: Weitere Erkenntnisse und weitere Fragen zum Flimser Bergsturz, Swiss Bulletin for Applied Geology, 11, 3543, 2006a.

Poschinger, A. v.: The stability of the Flims rockslide dam, Ital. J. Eng. Geol. Env., Special Issue 1, 87-91, doi:10.4408/IJEGE.2006-01.S-10, 2006b.

Poschinger, A. v. and Kippel, K.: Alluvial deposits liquefied by the Flims rock slide, Geomorphology, 103, 50-56, doi:10.1016/j.geomorph.2007.09.016, 2009.

Renner, F.: Beiträge zur Gletscher-Geschichte des Gotthardgebietes und Dendroklimatologische Analysen an fossilen Hölzern, $\mathrm{PhD}$ thesis, Geographisches Institut, Universität Zürich, Schweiz, Physische Geographie, 8, 182 pp., 1982.

Sartori, M., Ornstein, P., Métraux, C., and Kuehni, A.: Du levé géologique à la cartographie numérique, Geomatique Expert, 49, 38-41, 2006.

Scapozza, C.: Stratigraphie, morphodynamique, paléoenvironnements des terrains sédimentaires meubles à forte déclivité du domaine périglaciaire alpin, $\mathrm{PhD}$ thesis, Institut de géographie et durabilité, Université de Lausanne, Suisse, Géovisions, 40, 551 pp., 2013.

Scapozza, C. and Fontana, G.: Le Alpi Bleniesi. Storia glaciale e periglaciale e patrimonio geomorfologico, Memorie della Società ticinese di Scienze naturali e del Museo cantonale di storia naturale, Lugano, 10, 1-111, 2009.

Scapozza, C., Castelletti C., Soma, L., Dall'Agnolo, S., and Ambrosi C.: Timing of LGM and deglaciation in the Southern Swiss Alps, Géomorphologie, 4, 307-322, 2014.

Schneider, M. and Otto, J.-C.: A new semi-automatic tool for 3dimensional landform mapping, Grazer Schriften der Geographie und Raumforschung, 43, 235-242, 2007.

Strasky, S., Vandelli, A., Schreiber, L., Sartori, M., Ornstein, P., and Möri, A.: TOOLMAP2 - a powerful tool for digital mapping, Swiss Bulletin for Applied Geology, 16, 87-95, 2011.

Theler, D., Reynard, E., and Bardou, E.: Assessing sediment dynamics from geomorphological maps: Bruchi torrential system, Swiss Alps, Journal of Maps, 4, 277-289, doi:10.4113/jom.2008.1013, 2008.

Ustaszewski, M. and Pfiffner, O. A.: Neotectonic faulting, uplift and seismicity in the central and western Swiss Alps, in: Tectonic Aspects of the Alpine-Dinaride-Carpathian System, Geological Society, London, England, Special Publications, 298, 231-249, 2008.

Ustaszewski, M., Hampel, A., and Pfiffner, O. A.: Composite faults in the Swiss Alps formed by the interplay of tectonics, gravitation and postglacial rebound: an integrated field and modeling study, Swiss J. Geosci., 101, 223-235, doi:10.1007/s00015-008-12491,2008

Wassmer, P., Schneider, J.-L. M., Pollet, N., and Schmitter-Voirin, C.: Effects of the internal structure of a rock-avalanche dam on the drainage mechanism of its impoundment, Flims sturzstrom and Ilanz paleo-lake, Swiss Alps, Geomorphology, 61, 3-17, doi:10.1016/j.geomorph.2003.11.003, 2004.

Whitmeyer, S. J., Nicoletti, J., and De Paor, D. G.: The digital revolution in geologic mapping, GSA Today, 20, 4-10, doi:10.1130/GSATG70A.1, 2010.

Wiederkehr M. and Möri A.: swissALTI3-D - a new tool for geological mapping, Swiss Bulletin for Applied Geology, 18, 61-69, 2013. 